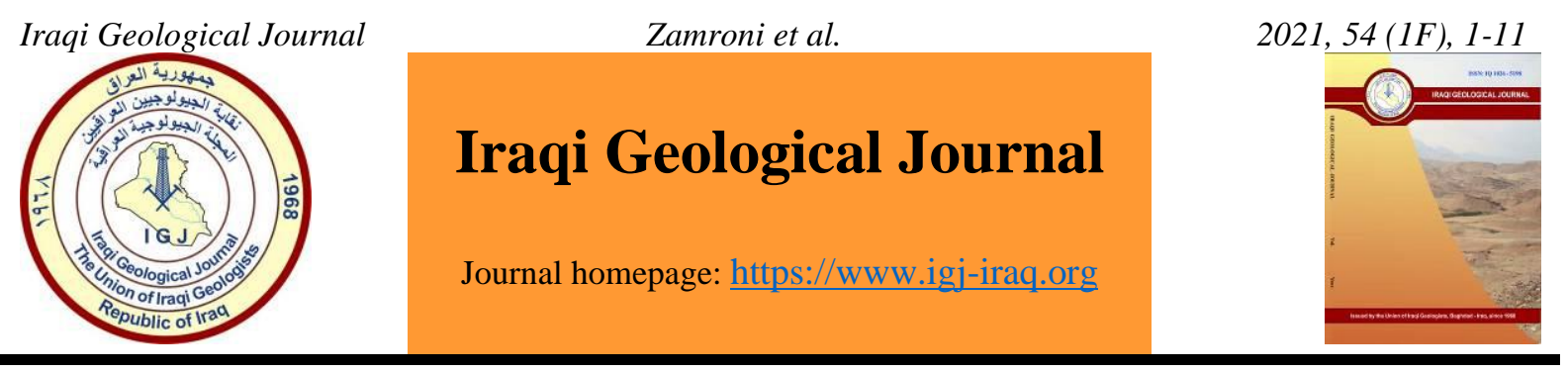

\title{
Geochemical Approach for Seawater Intrusion Assessment in the Area around Yogyakarta International Airport, Indonesia
}

\author{
Akhmad Zamroni $^{1}$, Oky Sugarbo ${ }^{1}$, Paramitha Tedja Trisnaning ${ }^{1}$, Saurina Tua Sagala ${ }^{2}$ and \\ Adam Sukma Putra ${ }^{3, *}$ \\ 1 Department of Geological Engineering, Institut Teknologi Nasional Yogyakarta, Jl Babarsari, Caturtunggal, Depok, \\ Sleman, Yogyakarta 55281, Indonesia \\ 2 Department of Mining Engineering, Institut Teknologi Nasional Yogyakarta, J1 Babarsari, Caturtunggal, Depok, \\ Sleman, Yogyakarta 55281, Indonesia \\ 3 Geophysics Division, Department of Physics, Faculty of Mathematics and Natural Science, Universitas Gadjah Mada, \\ J1 Bulaksumur, Yogyakarta 55281, Indonesia \\ * Correspondence: adamsukmaputra@ugm.ac.id
}

Received: 5 March 2021; Accepted: 17 April 2021; Published: 30 June 2021

\begin{abstract}
A total of 10 groundwater samples were obtained from groundwater wells with depths of around 8-10 meters distributed around Yogyakarta International Airport, Indonesia to test the geochemical of groundwater for assessing the seawater intrusion. Samples were taken into polyethylene bottles with a volume of $1000 \mathrm{ml}$. These bottles were rinsed to reduce the risk of any contamination prior to their filing with sampled water. Piper Diagram is used to evaluate seawater intrusion by plotting the percentages of cations and anions (in $\mathrm{mEq} / \mathrm{L}$ ) as a single point on the triangle. The groundwater facies' in the study area are $\mathrm{CaHCO}_{3}$ and $\mathrm{CaNaHCO}_{3}$. It suggests that the origins of the elements $\mathrm{Ca}$ and $\mathrm{Na}$ were estimated to derive from the dissolution of the plagioclase, hornblende, and pyroxene minerals found in the sand sediment, while the elements of $\mathrm{HCO}_{3}$ were estimated from the dissolution of carbonate minerals or the decomposition of organic matter and root respiration in the soil zone may enrich their concentration. The wells affected by slightly freshening were ZAM-04, ZAM-05, ZAM-06, ZAM-08, and ZAM-10. While the wells that are not affected by the intrusion or fresh were ZAM-01, ZAM-03, ZAM-07, and ZAM-09. However, ZAM-02 well which is close to the coastline and the closest to the airport development area was the only well that affected significantly by freshening, comparing with other wells. Another expected controlling factor was the fault in the northern part which continuously leads that location. By supported a flow pattern or large river, it was concluded the alluvial deposits buried the fault, and it was estimated to continue to that location.
\end{abstract}

Keywords: Piper Diagram; Groundwater facies; Freshening; Cation; Anion

\section{Introduction}

Yogyakarta International Airport (YIA) master plan was unveiled on 7 August 2012 and was classified as a public international airport due to the restriction of Adisucipto International Airport facilities as an international airport in the province of Daerah Istimewa Yogyakarta, Indonesia. There are some requirements for deciding this airport, such as adequate land for the long runway, land layout

DOI: $\underline{10.46717 / \text { igj.54.1F.1ms-2021-06-21 }}$ 
for the orientation of the runway, ability to avoid vital obstacles, suitable topography, limited resident resettlement, the situation outside the volcanic zone, catchment area, compliance with provincial legislation, and no existing contracts for mining leases. The Indonesian Government agreed in 2013 that the location of YIA is in Temon District, Kulonprogo Regency, Yogyakarta, Indonesia based on these factors (Tinasar et al., 2017). YIA was built to handle up to 20 billion passebased on ngers and was constructed in an area of over 587.2 ha in the southern part of Java Island (Rachman et al., 2018).

In the coastal areas, the construction of buildings is typically carried out by intense pumping. To support underground infrastructure and building foundations in urban coastal areas, extensive pumping to lower the water table is carried out. This method, however, can threaten the quality of groundwater as it can cause seawater intrusion. Furthermore, that activity can increase land subsidence, unstable buildings, and corrosion of concrete structures (Mas-Pla et al., 2013). Coastal areas, especially in areas where groundwater is over-pumped, are generally vulnerable to seawater intrusion. Owing to the overextraction of groundwater, seawater interference is the biggest problem in coastal areas, and it contributes to the deterioration of the freshwater aquifers' qualities. The extent of seawater intrusion is affected by the hydraulic gradient, geological settings, groundwater extraction rate, and its renewability (Senthilkumar et al., 2019). Seawater intrusion is the penetration of seawater into enclosed unconfined coastal aquifers, which in turn affects groundwater quality (Nair et al., 2015). Seawater intrusion is the flow of seawater into a freshwater aquifer. The degree of penetration of seawater in an aquifer depends on the volume and level of groundwater, the gap between the aquifer, the channels of seawater, drainage sources, geological structure, and the aquifer's hydraulic properties (Arslan et al., 2012). Many features of the aquifer, which may include groundwater flow paths, lithology, and anthropogenic activity such as pumping affect seawater intrusion (Muhammad and Husam, 2011). Furthermore, as sea levels increase, seawater can percolate through groundwater, causing seawater to migrate to land, resulting in a change in the quality of groundwater resources ( $\mathrm{Nu}$ et al., 2020). The seawater, which is slightly denser, initially invades the bottom of the aquifer and the freshwater present at the surface, as the coastal aquifers are normally hydraulically related to the sea. To meet the rising demand, over-exploitation of groundwater from such coastal aquifers accelerates the progress of seawater further into the shore. This would contribute to the closure of manufacturing wells due to groundwater pollution due to the mixing of seawater (Nair et al., 2015). Seawater intrusion into coastal aquifers is a natural phenomenon that gradually triggers the issue of groundwater salinization. In particular, it is in areas where semi-arid conditions lead to high pumping and low recharge extraction rates. The accumulation of seawater jeopardizes the future exploitation of coastal aquifers. It is a major concern in many coastal aquifers. Most agricultural crops are severely affected by the high salinity of water resources, seriously reducing yields and harming low salt tolerance crops, while wells with salinity concentration levels injecting water that exceed drinking water requirements cease production (Petalas et al., 2009). Groundwater, as a natural resource, is required in both urban and rural environments for the secure and commercial supply of potable water for the well-being of humans, certain aquatic, and terrestrial ecosystems. Recently, with the construction of electricity, agriculture, urbanization, industry growth, ecoenvironment construction, and improvements in living standards, water demand has increased rapidly. In today's existence, assessing the consistency and suitability of groundwater for different utilitarian purposes is of additional concern. Therefore, studies relating to the interpretation of groundwater geochemical characteristics, the geochemical processes involved, and their evolution in natural water circulation processes not only contribute to the efficient use and conservation of this important resource but also help to envisage improvements in the environment of the groundwater (Ravikumar and Somashekar, 2017). A geochemical approach for seawater intrusion assessment has been conducted by some researchers during last decade (Han et al., 2011; Rao et al., 2011; Agoubi et al., 2013; Garing et al., 2013; Kura et al., 2014; Nair et al., 2015; Eissa et al., 2016; Isawi et al., 2016; Liu et al., 2016; Supriyadi et al., 2017; Kanagaraj et al., 2018; Naseem et al., 2018; Shi et al., 2018; Bahera et al., 2019; 
Fortuna et al., 2020; Seddique at al. 2019; Dhakate et al., 2020; Sae et al., 2020; Satheeskumar et al., 2020; Shin et al., 2020; Telahigue et al., 2020; Wang et al., 2020). A variety of dynamic geochemical processes can also include seawater intrusion into the aquifers. The groundwater interacts with the surrounding rocks during natural hydrological cycling, triggering a number of geochemical processes that modify chemical components of groundwater on a local or regional scale. The geochemical processes responsible for altering groundwater's chemical composition differ with regard to space and time. Therefore, geochemical analysis is a critical instrument for quality assessment (Thin et al., 2018). With the length of its flow routes, the chemical constituents of groundwater begin to increase. Due to ion exchange and precipitation of least soluble salts first, the composition of water at an outcrop is altered when it passes through the ground. Groundwater progresses into the composition of seawater chemically. Rainfall, recharging, atmosphere, aquifer lithology, saline water, soil, air, and flow patterns are the major geological and hydrogeological factors that usually influence geochemical of groundwater (Al-Agha and El-Nakhal, 2004). $\mathrm{Na}^{+}, \mathrm{Mg}^{2+}, \mathrm{Ca}^{2+}, \mathrm{K}^{+}, \mathrm{Cl}^{-}, \mathrm{SO}^{2-}, \mathrm{NO}_{3}{ }^{-}$, and $\mathrm{HCO}_{3}{ }^{-}$are the main cations and anions in the geochemical study of groundwater. The groundwater quality is influenced by these cations and anions (Zghibi et al., 2012; Fathi Ubeid and Al-Agha, 2020). In addition, Electrical Conductivity (EC) value in the groundwater analysis is a physical parameter that important to determine seawater intrusion (Shin and Hwang 2020). Therefore, it is necessary and urgent to understand how geochemical environments regulate groundwater evolution and how hydrogeological conditions constrain circulation (Zhang et al., 2015). In addition, a distinct geochemical signature is created by the saline intrusion into fresh groundwater systems. Mixing various types of water may cause reactions that contribute to a water composition that is different from a conservative mixture. The dominant ions in seawater are chloride and sodium, but ion exchange takes place when this salty water comes into contact with a fresh groundwater environment where calcium dominates the clay (Muhammad and Husam, 2011). The chemical composition often influences the consistency of groundwater. The study of the dissolved ions, acidity $(\mathrm{pH})$, hardness, Electrical Conductivity (EC), and alkalinity are normally performed to classify geochemical properties. The groundwater geochemical is the key to learn the origins, geochemical processes, hydrodynamics, and interactions of groundwater with aquifer matrix. Groundwater geochemistry influences by natural and anthropogenic factors. Natural factors include the characteristics of aquifers (geology), vegetation, climate, and even natural catastrophes (earthquakes, droughts, floods, etc.), while the anthropogenic factors include human activities and land-use changes like mining, agriculture, manufacturing, landfill sites, and domestic areas (Poetra et al., 2020). The variations in the chemical composition of fresh groundwater are due to mixing as well as chemical reactions such as ion exchange processes (Seddique et al., 2019). The purpose of this study is to assess the seawater intrusion in the area around Yogyakarta International Airport by geochemical analysis. This study has a benefit as guidelines for the future policy of groundwater using.

\section{Geology and Hydrogeology of the Study Area}

The study area is situated on the southern side of the Yogyakarta Quadrangle in the coastal area of Kulonprogo Regency. The exposed formation in the study area from oldest to youngest are Andesite, Old Andesite Formation (Upper Oligocene), Sentolo Formation (Lower Miocene to Middle Miocene), and Quarterly Alluvium. Andesite is a part of the central-proximal facies of each Tertiary volcano body in the Kulon Progo Mountains. It has become fragile as a result of deformation caused by tectonic forces. As a consequence, if there is a tectonic force, the rocks are more likely to break (Widagdo et al., 2018). Old Andesite Formation consists of andesite volcanic breccia, tuff, lapilli breccia, lapilli tuff, fragments of the andesite lava flow, fragments of volcanic sandstone, and agglomerates. Sentolo Formation consists of limestone, marl sandstones, marl tuff-boarded conglomerate, and a glass tuff in the lower section. It is part of some volcanic material from the formation of volcanic OAFs. These rocks gradually turned upwards into a well layered limestone rich 
in Foraminifera. Quarterly Alluvium consists mainly of alluvial deposits distributed along the large rivers and coastal plains. These sediments are composed of gravel, sand, silt, and clay. The alluvial plain is alluvial soil from volcanic rock. On the east side, the west, and south of the Kulonprogro plain, alluvial deposits can be found. The coastal alluvial sand deposits in the south of the Kulonprogro region along the coastal area (Widagdo et al., 2016). In the area around Kulonprogo, Total Dissolved Solids (TDS) appear to be high on steep slopes. In coastal ridge, sand dune complex, swale, and coastal area, this phenomenon does not occur because it is included as a local aquifer directly recharged by rainwater, resulting in a very low TDS value. The consequence of the different geomorphological aspects is that the hydrogeochemical processes of groundwater have a typical geochemical portion that exist in each landform. Dissolution of hydroxide oxide (ferrihydrite and wustite), calcite, diaspore, albite, and gibbsite are the geochemical of groundwater processes occurring in denudational hills towards alluvial plains. Consequently, there is a trend towards increasing $\mathrm{Na}^{+}$, quartz, $\mathrm{Fe}$ (total), $\mathrm{Ca}^{2+}$, and $\mathrm{Al}^{3+}$ concentrations. In this unit, there is also the mechanism of ion exchange on diaspores and albites and the half-reaction reduction process in ferrihydrite (if $\mathrm{Fe}^{2+}$ is formed). Albite dissolution is still continuing in the flow path from the alluvial plains to the fluviomarine plain, causing a rise in $\mathrm{Na}^{+}$and $\mathrm{SiO}_{2}$, contributing to precipitation of quartz minerals. It also dissolves oxide-hydroxide minerals like ferrihydrite, leading to a rise in Fe (total) concentration (Poetra et al., 2020). In the Piper diagram, the prominent geochemical facies are a form of water bicarbonate. In the distribution of geochemical facies of groundwater, seawater intrusion thus plays a minor role. In the region around Kulonprogo, a range of salinity values is noted. This is because of the large variety of coastal plains that exist in the Alluvial Plains. The presence of geochemical facies and close relation between groundwater and geological conditions (morphology and lithology) is therefore indicated. Geochemical facies can be beneficially used as data to enhance the understanding of geochemical of groundwater processes, to perform more detailed studies, and to handle better water supplies (Thin et al., 2018). The geological map of the study area is shown in Fig.1.

\section{Materials and Methods}

In September 2020 (dry season), a total of 10 groundwater samples were obtained from water wells with depths of around 8-10 meters distributed around Yogyakarta International Airport, Indonesia (Fig. 2.). Samples were taken in polyethylene bottles with a volume of $1000 \mathrm{ml}$. These bottles were rinsed to reduce the risk of any contamination prior to their filing with sampled water.

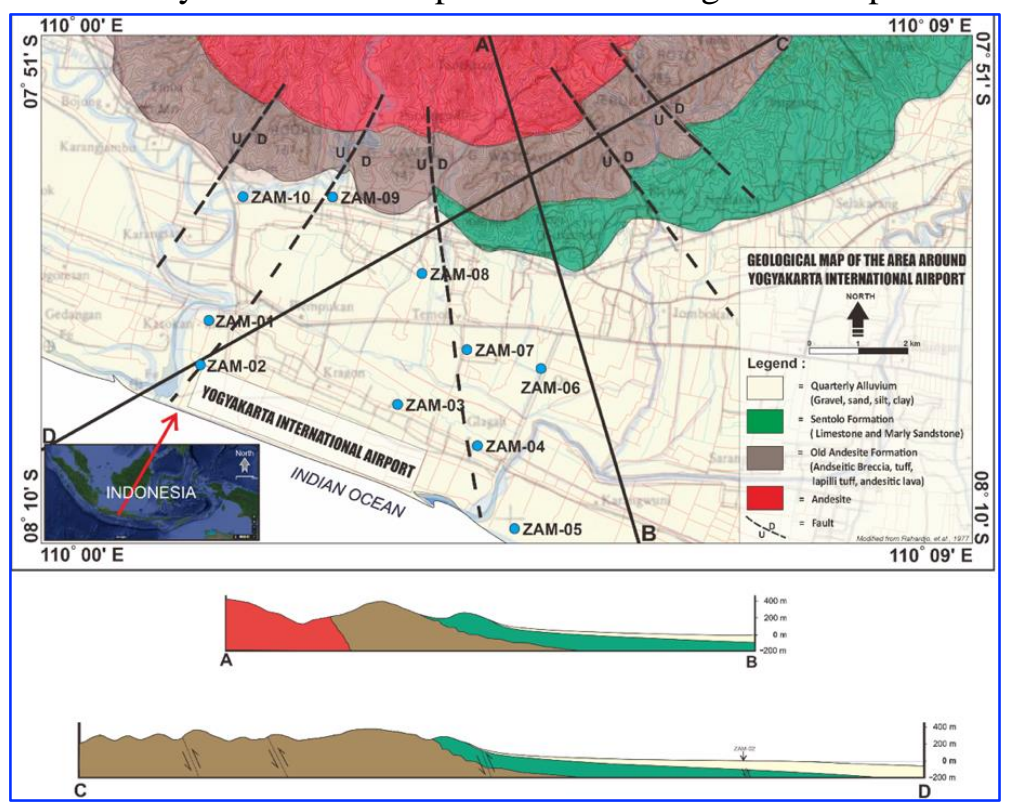

Fig.1. Geological map of the study area (Modified from Rahardjo et al.1995) 
The main ions: $\mathrm{Ca}^{2+}, \mathrm{Mg}^{2+}, \mathrm{Na}^{+}, \mathrm{K}^{+}, \mathrm{SO}_{4}{ }^{2}, \mathrm{HCO}_{3}{ }^{-}, \mathrm{Cl}^{-}$, and $\mathrm{NO}_{3}^{-}$were analyzed, and in situ Electrical Conductivity (EC) is measured. By the titrimetric method, magnesium $\left(\mathrm{Mg}^{2+}\right)$, sodium $\left(\mathrm{Na}^{+}\right)$, potassium $\left(\mathrm{K}^{+}\right)$, calcium $\left(\mathrm{Ca}^{2+}\right)$, bicarbonate $\left(\mathrm{HCO}_{3}{ }^{-}\right)$, and chloride $\left(\mathrm{Cl}^{-}\right)$ions were analyzed. A spectrophotometer was used to detect the sulfate $\left(\mathrm{SO}_{4}{ }^{2-}\right)$ and nitrate $\left(\mathrm{NO}_{3}{ }^{-}\right)$ions. The flame photometer was used to analyze the sodium $\left(\mathrm{Na}^{+}\right)$and potassium $\left(\mathrm{K}^{+}\right)$ions. Using a conductivity meter, Electrical Conductivity (EC) was measured. Piper Diagram is used to evaluate seawater intrusion by plotting the percentages of cations and anions (in $\mathrm{mEq} / \mathrm{L}$ ) as a single point on the triangle (Muhammad and Husam, 2011). Kelly (2005) developed a diagram to characterize seawater intrusion, using seven distinct grading criteria, from freshwater to conservative mixing water.

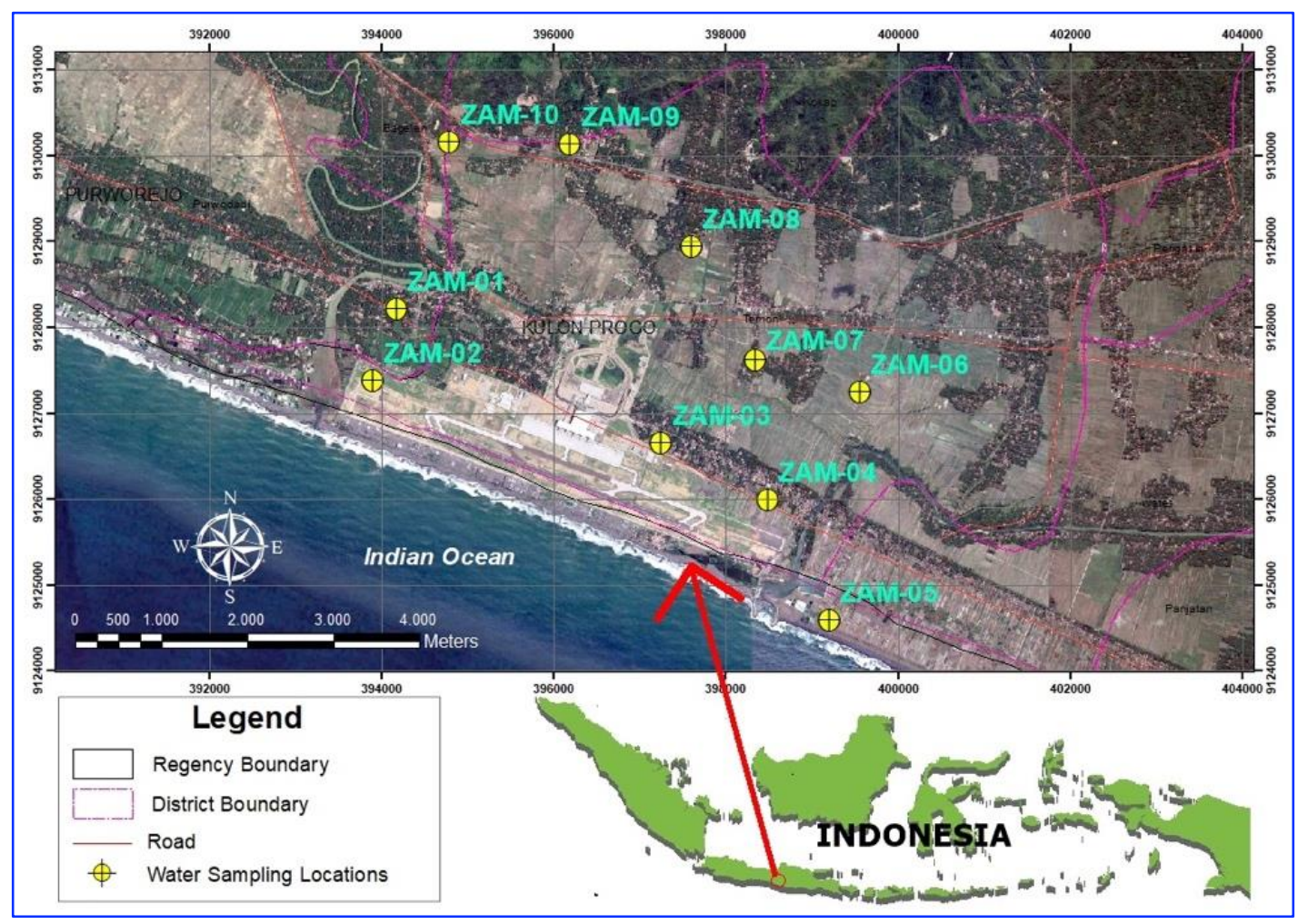

Fig.2. The satellite image shows the location of the study area and the groundwater sampling sites.

\section{Results and Discussion}

Table 1 shows the results of the hydrochemical analysis of groundwater in the study area. The chemical analysis results were verified for ion-balancing averages errors $(<15 \%)$. Electrical conductivity (EC) is a measure of current conduction potential and higher EC implies salt/dissolved matter enrichment in the groundwater. Water can be graded as type I on the basis of EC if the salt enrichment is low $(\mathrm{EC}<1,500 \mu \mathrm{S} / \mathrm{cm})$; type II if the salt enrichment is medium (EC: 1500 to $3000 \mu \mathrm{S} / \mathrm{cm}$ ); and type III if the salt enrichment is high (EC>3,000 $\mu \mathrm{S} / \mathrm{cm}$ ) (Rao et al. 2012). All the groundwater samples fall under type I (low enrichment of salts) in the study area except for one sample (ZAM-06), as belongs to the medium salt enrichment class (type II). Groundwater samples represented by low salt enrichment suggest that no seawater intrusion has occurred in the study area. A sample (ZAM-06) which has a medium salt enrichment was indicated that groundwater in the sampling location contact with the saltwater. The saltwater is probably come from seawater, connate water, or dissolved mineral elements (plagioclase, hornblende, and pyroxene) from sandstones, therefore, geochemical approach is assessed to answer that circumstance furthermore (Table 1). 
Table 1. Geochemical data of groundwater in the study area

\begin{tabular}{cccccccccc}
\hline Location & $\mathbf{C a}$ & $\mathbf{K}$ & $\mathbf{M g}$ & $\mathbf{N a}$ & $\mathbf{C l}$ & $\mathbf{S O}_{4}$ & $\mathbf{H C O}_{3}$ & $\mathbf{N O}_{3}$ & $\mathbf{E C}$ \\
& $(\mathbf{m g} / \mathbf{l})$ & $(\mathbf{m g} / \mathbf{l})$ & $(\mathbf{m g} / \mathbf{l})$ & $(\mathbf{m g} / \mathbf{l})$ & $(\mathbf{m g} / \mathbf{l})$ & $(\mathbf{m g} / \mathbf{l})$ & $(\mathbf{m g} / \mathbf{l})$ & $(\mathbf{m g} / \mathbf{l})$ & $(\boldsymbol{\mu S} / \mathbf{c m})$ \\
\hline ZAM-01 & 24 & 4 & 9.7 & 19 & 18.9 & 13.4 & 120 & 6.91 & 269 \\
ZAM-02 & 24 & 117 & 29.2 & 468 & 119 & 40.3 & 180 & 57.4 & 909 \\
ZAM-03 & 40 & 17 & 24.9 & 37 & 27.8 & 20.2 & 128 & 32.4 & 410 \\
ZAM-04 & 27 & 8 & 7.8 & 31 & 15.9 & 10.7 & 40 & 34.7 & 245 \\
ZAM-05 & 24 & 13 & 16.5 & 44 & 30.8 & 24.7 & 104 & 51.8 & 385 \\
ZAM-06 & 158 & 12 & 39.9 & 343 & 41.7 & 483 & 620 & 0.47 & 2650 \\
ZAM-07 & 58 & 3 & 23.3 & 47 & 33.8 & 12.3 & 304 & 0.24 & 639 \\
ZAM-08 & 40 & 2 & 20.4 & 37 & 13.9 & 8.78 & 276 & 0.53 & 486 \\
ZAM-09 & 53 & 2 & 19.4 & 25 & 20.8 & 21.7 & 228 & 0.71 & 474 \\
ZAM-10 & 29 & 6 & 11.7 & 22 & 10.9 & 5.49 & 158 & 0.41 & 168 \\
\hline
\end{tabular}

In the Piper Diagram, concentrations of the cations and anions were graphed. By using the trilinear plotting systems, the hydrochemical facies of groundwater is inferred (Piper 1944). The samples on the Piper diagram are labeled as several chemical facies (Fig.3.). According to Fig.3., the $\mathrm{CaHCO}_{3}$ facies (ZAM-01, ZAM-03, ZAM-07, ZAM-08, ZAM-09, and ZAM-10) and mixed $\mathrm{CaNaHCO}_{3}$ facies (ZAM02 , ZAM-04, ZAM-05, and ZAM-06) are the types of groundwater in the study area. It is estimated that the groundwater facies in the study area derived from alluvial deposits. Gravel, sand, silt, and clay along large rivers and coastal plains formed the alluvial deposit. The alluvial plain is composed of alluvial volcanic rock material (Widagdo et al., 2016). Sand sediment is divided into two types in the coastal area of Kulonprogo, namely, type 1 sand sediment and type 2 sand sediment. Type 1 sand sediment is gray sand, a mixture of mafic minerals, quartz, and coral reef fragments, while type 2 sand sediment is black sand, dominated by iron sand and limited mineral content of quartz. The source of these mafic minerals is the northern lithology of the Kulonprogo Mountains, dominated by mafic to intermediate types. In addition, iron $(\mathrm{Fe})$, hematite $\left(\mathrm{Fe}_{2} \mathrm{O}_{3}\right)$, rutile $\left(\mathrm{TiO}_{2}\right)$, and iron oxide $(\mathrm{FeO})$ are minerals in the Kulonprogo coastal sand sediments (Noviadi and Setiady, 2020). It can be understood from this assertion that silica and mafic minerals that are rich in $\mathrm{Fe}, \mathrm{Mg}$, and $\mathrm{Ca}$ dominate the minerals found in the sand deposits. The physicochemical conditions during deposition can be deduced from the chemical composition in the lithological features (Tobia and Mustafa, 2019). In addition, one of the deciding factors for lithological features is geologic history. The key to understanding past rock stories is their geologic history (Zamroni et al., 2020). $\mathrm{CaHCO}_{3}$ facies and $\mathrm{CaNaHCO}_{3}$ facies are the groundwater facies in the study area. It suggests that the origins of the elements $\mathrm{Ca}$ and $\mathrm{Na}$ were estimated to derive from the dissolution of the plagioclase, hornblende, and pyroxene minerals found in the sand sediment, while the elements of $\mathrm{HCO}_{3}$ were estimated to originate from two alternative sources. The main one is associated with the dissolution of carbonate minerals (calcite and dolomite) by carbonic acid, while the second one is the decomposition of organic matter and root respiration in the soil zone may enrich their concentration (Bouteldjaoui, 2020). It is also estimated that the carbonate minerals derive from the dissolution of coral reefs fragments. Moreover, hydrochemistry of the groundwater was used to assess seawater intrusion using a modified Piper Diagram (Kelly, 2005) (Fig.4.). According to Fig.4., the wells affected by slightly freshening were ZAM-04, ZAM-05, ZAM-06, ZAM-08, and ZAM-10. While the wells that are not affected by intrusion or fresh were ZAM-01, ZAM-03, ZAM-07, and ZAM-09. However, ZAM-02 well which is close to the coastline and the closest to the airport development area was the only well that affected significantly by freshening, comparing with other wells. Both a drop-in groundwater pumping and coastal reclamation caused the aquifer freshening, which shifted the interface between fresh groundwater and seaward saline groundwater. The aquifer will be recharged in such a 
way that the system is predominantly regulated by natural topography-driven flow through the shallow soil and outcrops of the aquifer, contributing to the gradual refreshing of the coastal aquifer that once endured the seawater intrusion (Chen and Jiao, 2007).

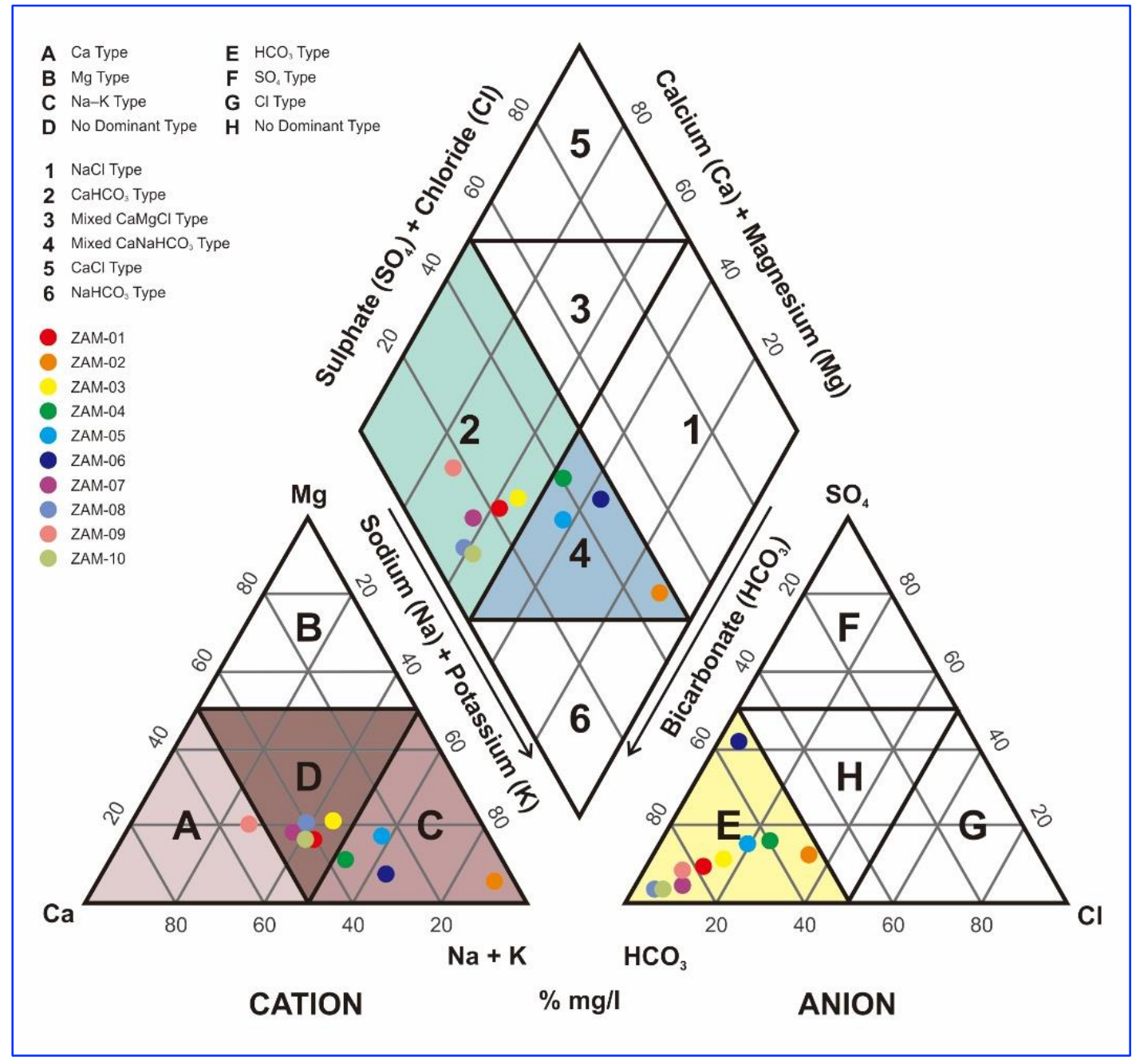

Fig. 3. Piper Diagram of major chemical components of groundwater in the study area

According to the data analysis, the location of wells affected by freshening was not always near to the sea and vice versa. It means the freshening process was estimated due to groundwater overpumping in some locations or it has occurred in the river when the river freshwater contacted seawater and it affected the well near the locations. But ZAM-02 well was the only location affected by freshening, this condition was estimated not only the position of the well of ZAM-02 which was close to the coastline but also the closest to the airport development area. It can cause the groundwater level in the aquifer to be lower than the sea level so that seawater would intrude into the landward. Another controlling factor was the fault in the northern part which continuously leads that location. The Digital Elevation Model (DEM) shows an alignment pattern at the study area which indicates a fault (Fig.5.). By supported a flow pattern or large river, it was concluded the alluvial deposits buried the fault, and it was estimated to continue to that location. This fault can become a route for the entry of seawater into freshwater. 


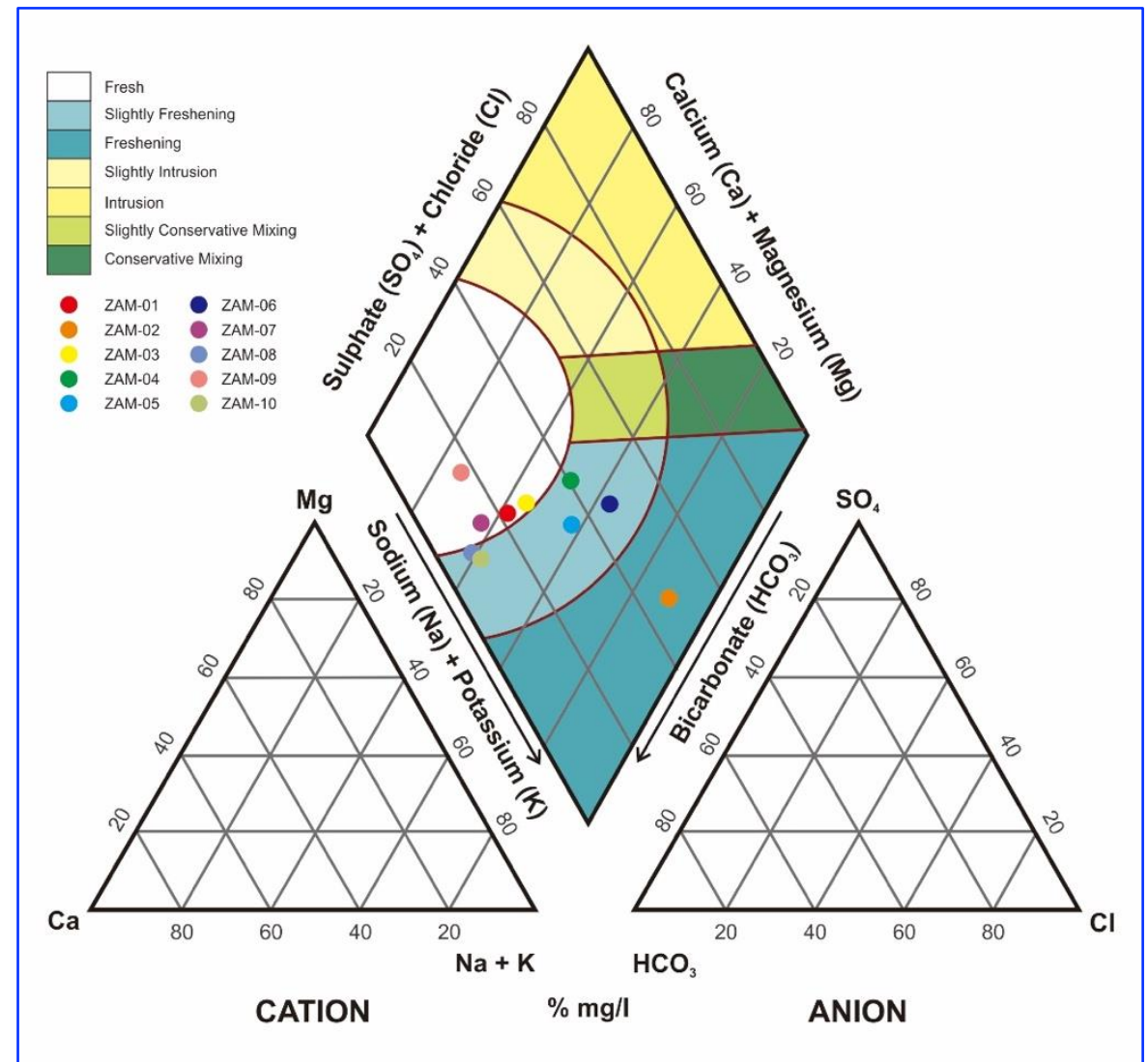

Fig.4. Assessing seawater intrusion in the study area using a modified Piper Diagram

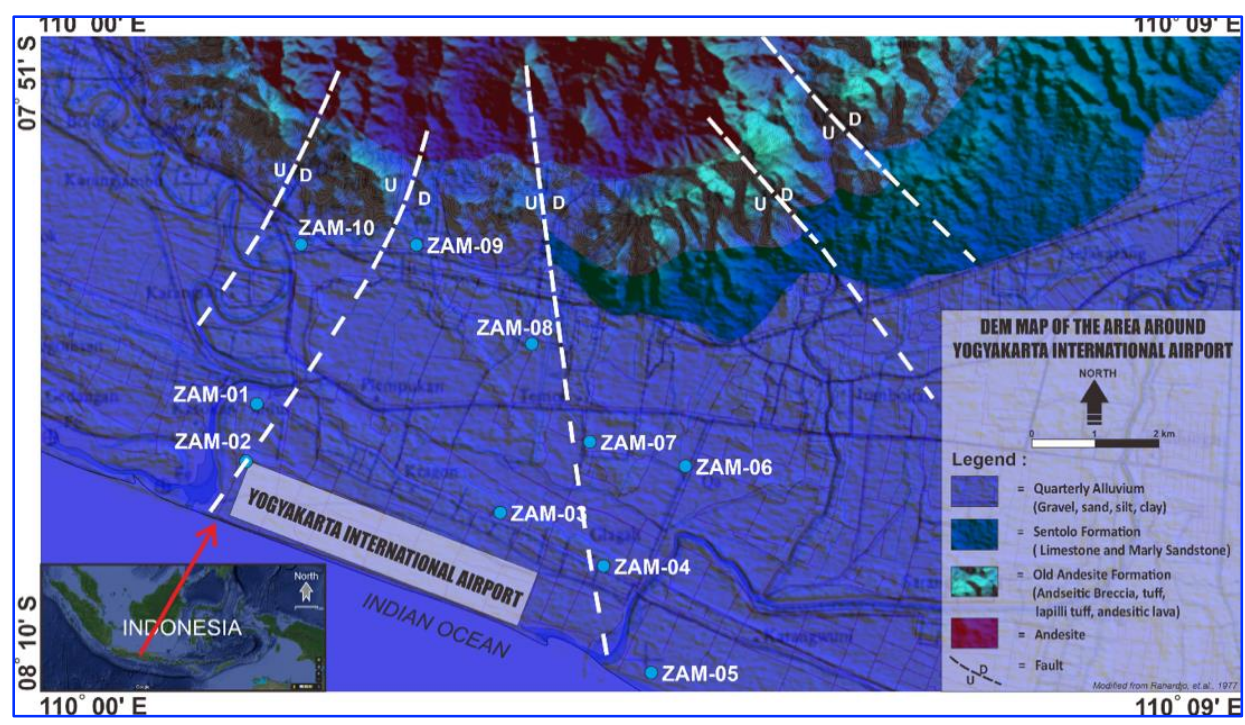

Fig.5. The digital elevation model (DEM) at the study area.

\section{Conclusions}

The wells affected by slightly freshening were ZAM-04, ZAM-05, ZAM-06, ZAM-08, and ZAM10. While the wells that are not affected by intrusion or fresh were ZAM-01, ZAM-03, ZAM-07, and ZAM-09. However, ZAM-02 well which is close to the coastline and the closest to the airport development area was the only well that affected significantly by freshening, comparing with other wells. It suggests that the origins of the elements $\mathrm{Ca}$ and $\mathrm{Na}$ were estimated to derive from the dissolution 
of the plagioclase, hornblende, and pyroxene minerals found in the sand sediment, while the elements of $\mathrm{HCO}_{3}$ were estimated to originate from two alternative sources. The main one is associated with the dissolution of carbonate minerals (calcite and dolomite) by carbonic acid, while the second one is the decomposition of organic matter and root respiration in the soil zone may enrich their concentration. The wells affected by slightly freshening were ZAM-04, ZAM-05, ZAM-06, ZAM-08, and ZAM-10. While the wells that are not affected by intrusion or fresh were ZAM-01, ZAM-03, ZAM-07, and ZAM09. However, ZAM-02 well which is close to the coastline and the closest to the airport development area was the only well that affected significantly by freshening, comparing with other wells. ZAM-02 well was the only location affected by freshening, this condition was estimated not only the position of the well of ZAM-02 which was close to the coastline but also the closest to the airport development area. It can cause the groundwater level in the aquifer to be lower than the sea level so that seawater would intrude into the landward. Another controlling factor was the fault in the northern part which continuously leads that location.

\section{Acknowledgements}

We thank the Institut Teknologi Nasional Yogyakarta, Universitas Gadjah Mada, and Direktorat Riset dan Pengabdian Masyarakat, Deputi Bidang Penguatan Riset dan Pengembangan, Kementerian Riset, Teknologi / Badan Riset dan Inovasi Nasional Republik Indonesia for the support research funding. In addition, we thank field assistants (Haris Nur Eka Prasetya and Al Hussein Flowers Rizqi, M.Eng.) who guide us to take water samples. The authors are very grateful to the Editor in chief Prof. Dr. Salih M. Awadh, the Secretary of Journal Mr. Samir R. Hijab. and the Technical Editors for their great efforts and valuable comments.

\section{References}

Agoubi, B., Kharroubi, A., Abida, H., 2013. Saltwater intrusion modelling in Jorf coastal aquifer, South-eastern Tunisia: geochemical, geoelectrical and geostatistical application. Hydrological Processes, 27(8),11911199.

Al-Agha, M.R., El-Nakhal, H.A., 2004. Hydrochemical facies of groundwater in the Gaza Strip, Palestine/Faciès hydrochimiques de l'eau souterraine dans la Bande de Gaza, Palestine. Hydrological Sciences Journal, 49(3), 359-371.

Arslan, H., Cemek, B., Demir, Y., 2012. Determination of seawater intrusion via hydrochemicals and isotopes in Bafra Plain, Turkey. Water Resources Management, 26(13),3907-3922.

Behera, A.K., Chakrapani, G.J., Kumar, S., Rai, N., 2019. Identification of seawater intrusion signatures through geochemical evolution of groundwater: a case study based on coastal region of the Mahanadi delta, Bay of Bengal, India. Natural Hazards, 97(3), 209-1230.

Bouteldjaoui, F., 2020. Re: What is the source of bicarbonate $\left(\mathrm{HCO}_{3}\right)$ in noncalcareous aquifers?

Chen, K.P., Jiao, J.J., 2007. Seawater intrusion and aquifer freshening near reclaimed coastal area of Shenzhen. Water Science and Technology: Water Supply, 7(2), 137-145.

Dhakate, R., Ratnalu, G.V., Sankaran, S., 2020. Hydrogeochemical and isotopic study for evaluation of seawater intrusion into shallow coastal aquifers of Udupi District, Karnataka, India. Geochemistry.

Eissa, M.A., Mahmoud, H.H., Shouakar-Stash, O., El-Shiekh, A., Parker, B., 2016. Geophysical and geochemical studies to delineate seawater intrusion in Bagoush area, Northwestern coast, Egypt. Journal of African Earth Sciences, 121, 365-381.

Fathi Ubeid, K., Al-Agha, M.R., 2020. Water types and carbonate saturation model of groundwater in middle Governorate (Gaza strip, Palestine). Iranian Journal of Earth Sciences, 12(2), 87-97.

Fortuna, D.A., Daud, Y., Abidin, Z., 2020. Study on geochemistry of sea water intrusion effect in Jailolo geothermal system. In: IOP Conference Series: Earth and Environmental Science: IOP Publishing.

Garing, C., Luquot, L., Pezard, P.A., Gouze, P., 2013. Geochemical investigations of saltwater intrusion into the coastal carbonate aquifer of Mallorca, Spain. Applied Geochemistry, 39,1-10. 
Han, D., Kohfahl, C., Song, X., Xiao, G., Yang, J., 2011. Geochemical and isotopic evidence for palaeo-seawater intrusion into the south coast aquifer of Laizhou Bay, China. Applied Geochemistry, 26(5), 863-883.

Isawi, H., El-Sayed, M.H., Eissa, M., Shouakar-Stash, O., Shawky, H., Mottaleb, M.S.A., 2016. Integrated geochemistry, isotopes, and geostatistical techniques to investigate groundwater sources and salinization origin in the Sharm EL-Shiekh Area, South Sinia, Egypt. Water, Air, \& Soil Pollution, 227(5),151.

Kanagaraj, G., Elango, L., Sridhar, S.G.D., Gowrisankar, G., 2018. Hydrogeochemical processes and influence of seawater intrusion in coastal aquifers south of Chennai, Tamil Nadu, India. Environmental Science and Pollution Research, 25(9), 8989-9011.

Kelly, F., 2005. Seawater intrusion Topic paper: Island Country Health Department

Kura, N.U., Ramli, M.F., Ibrahim, S., Sulaiman, W.N.A., Aris, A.Z., 2014. An integrated assessment of seawater intrusion in a small tropical island using geophysical, geochemical, and geostatistical techniques. Environmental Science and Pollution Research, 21(11), 7047-7064.

Liu, H., Hisby, K., Zhou, Y., Ma, Z., Chen, S., Guo, X., 2016. Features and evaluation of sea/saltwater intrusion in southern Laizhou Bay. Journal of Groundwater Science and Engineering, 4(2),141-148.

MasPla, J., RodríguezFlorit , A., Zamorano, M., Roqué, C., Menció, A., Brusi, D., 2013. Anticipating the effects of groundwater withdrawal on seawater intrusion and soil settlement in urban coastal areas. Hydrological Processes, 27(16), 2352-2366.

Muhammad, A.K., Husam, A.N., 2011. Hydro-geochemical characteristics of groundwater beneath the Gaza strip. Journal of Water Resource and Protection, 3, 341-348.

Nair, I. S., Rajaveni, S.P., Schneider, M., Elango, L., 2015. Geochemical and isotopic signatures for the identification of seawater intrusion in an alluvial aquifer. Journal of Earth System Science, 124(6), 12811291.

Naseem, S., Bashir, E., Ahmed, P., Rafique, T., Hamza, S., Kaleem, M., 2018. Impact of seawater intrusion on the geochemistry of groundwater of Gwadar District, Balochistan and its appraisal for drinking water quality. Arabian Journal for Science and Engineering, 43(1), 281-293.

Noviadi, Y., Setiady, D., 2020. Sedimentasi pasir sepanjang pantai Kulon Progo, Daerah Istimewa Yogyakarta. Jurnal Geologi Kelautan, 18(1).

Nu, N.T., Duong, N.T., Son, B.T., Thinh, P.H., 2020. Investigation of salt, alum content in soft soils and their effects on soil properties: case study in coastal areas of Vietnam. Iraqi Geological Journal, 19-34.

Petalas, C., Pisinaras, V., Gemitzi, A., Tsihrintzis, V.A., Ouzounis, K., 2009. Current conditions of saltwater intrusion in the coastal Rhodope aquifer system, northeastern Greece. Desalination, 237(1-3), 22-41.

Piper, A. M., 1944. A graphic procedure in the geochemical interpretation of water-analyses. Eos, Transactions American Geophysical Union, 25(6), 914-928.

Poetra, R.P., Adji, T.N., Santosa, L.W., Khakhim, N., 2020. Hydrogeochemical Conditions in Groundwater Systems with Various Geomorphological Units in Kulonprogo Regency, Java Island, Indonesia. Aquatic Geochemistry, 1-34.

Rachman, F., Satriagasa, M.C., Riasasi, W., 2018. Economic impact studies on development project of New Yogyakarta International Airport to aquaculture in Kulonprogo Coastal. E\&ES, 139(1):012037.

Rahardjo, W., Sukandarrumidi, Rosidi, H.M.D., 1995. Peta Geologi Lembar Yogyakarta, Pusat Penelitian dan Pengembangan Geologi, Bandung

Rao, N.S., Rao, P.S., Reddy, G.V., Nagamani, M., Vidyasagar, G., Satyanarayana, N.L.V.V., 2012. Chemical characteristics of groundwater and assessment of groundwater quality in Varaha River Basin, Visakhapatnam District, Andhra Pradesh, India. Environmental Monitoring and Assessment, 184(8), 51895214.

Rao, V.G., Rao, G.T., Surinaidu, L., Rajesh, R., Mahesh, J., 2011. Geophysical and geochemical approach for seawater intrusion assessment in the Godavari Delta Basin, AP, India. Water, Air, \& Soil Pollution, 217(14), 503-514.

Ravikumar, P., Somashekar, R.K., 2017. Principal component analysis and hydrochemical facies characterization to evaluate groundwater quality in Varahi river basin, Karnataka state, India. Applied Water Science, 7(2),745-755. 
Sae-Ju, J., Chotpantarat, S., Thitimakorn, T., 2020. Hydrochemical, geophysical and multivariate statistical investigation of the seawater intrusion in the coastal aquifer at Phetchaburi Province, Thailand. Journal of Asian Earth Sciences, 191, 104165.

Satheeskumar, V., Subramani, T., Lakshumanan, C., Roy, P.D., Karunanidhi, D., 2020. Groundwater chemistry and demarcation of seawater intrusion zones in the Thamirabarani delta of south India based on geochemical signatures. Environmental Geochemistry and Health, 1-14.

Seddique, A.A., Masuda, H., Anma, R., Bhattacharya, P., Yokoo, Y., Shimizu, Y., 2019. Hydrogeochemical and isotopic signatures for the identification of seawater intrusion in the paleobeach aquifer of Cox's Bazar city and its surrounding area, south-east Bangladesh. Groundwater for Sustainable Development, 9,100215.

Senthilkumar, S., Vinodh, K., Babu, G.J., Gowtham, B., Arulprakasam, V. 2019. Integrated seawater intrusion study of coastal region of Thiruvallur district, Tamil Nadu, South India. Applied Water Science, 9(5), 124.

Shi, X., Wang, Y., Jiao, J.J., Zhong, J., Wen, H., Dong, R., 2018. Assessing major factors affecting shallow groundwater geochemical evolution in a highly urbanized coastal area of Shenzhen City, China. Journal of Geochemical Exploration, 184,17-27.

Shin, J., Hwang, S., 2020. A Borehole-based approach for seawater intrusion in heterogeneous coastal aquifers, eastern part of Jeju Island, Korea. Water Journal, 12(2), 609.

Shin, K., Koh, D. C., Jung, H., Lee, J., 2020. The hydrogeochemical characteristics of groundwater subjected to seawater intrusion in the Archipelago, Korea. Water, 12(6),1542.

Supriyadi, K., Putro, A.S.P., 2017. Geophysical and hydrochemical approach for seawater intrusion in North Semarang, Central Java Indonesia. International Journal of Geomate, 12(31),134-140.

Telahigue, F., Mejri, H., Mansouri, B., Souid, F., Agoubi, B., Chahlaoui, A., Kharroubi, A., 2020. Assessing seawater intrusion in arid and semi-arid Mediterranean coastal aquifers using geochemical approaches. Physics and Chemistry of the Earth, Parts A/B/C, 115, 102811.

Thin, P.P., Hendrayana, H., Wilopo, W., Kawasaki, S., 2018. Assessment of groundwater facies in Wates Coastal Area, Kulon Progo, Yogyakarta, Indonesia. Journal of Degraded and Mining Lands Management, 5(4):1389.

Tinasar, A.I., Saputra, R.H., Sahid, S., 2017. Evaluation of New Yogyakarta International Airport (NYIA) in Temon District Based on Tsunami Disaster Risk using Geographic Information System (GIS). Universitas Muhammadiyah Surakarta: 90-102.

Tobia, F.H., Mustafa, B.H., 2019. Provenance and depositional environment of the carbonates from Baluti Formation (Late Triassic), Kurdistan Region, Iraq. Iraqi Geological Journal, 18-35.

Wang, H., Chen, Q., Wei, J., Ji, Y., 2020. Geochemical characteristics and influencing factors of groundwater Fe in seawater intrusion area. Water, Air, \& Soil Pollution, 231(7),1-11.

Widagdo, A., Pramumijojo, S., Harijoko, A., Setiawan, A., 2016. Preliminary Overview of the Character, Patterns and Styles of The Geologic Structure of Kulon Progo Mountains Area and Its Potential as a Source of The Geological Structural Damage. In: Proceedings International Conference Jogja Earthquake in Reflection, Universitas Pembangunan Nasional, Yogyakarta.

Widagdo, A., Pramumijoyo, S., Harijoko, A., \& Setiyanto, A., 2018. Fault lineaments control on disaster potentials in Kulon Progo Mountain Area-Central Java-Indonesia. In MATEC, 229, 03008. EDP Sciences.

Zamroni, A., Sugarbo, O., Prastowo, R., Widiatmoko, F.R., Safii, Y., Wijaya, R.A.E., 2020. The relationship between Indonesian coal qualities and their geologic histories. In: AIP Conference Proceedings: AIP Publishing LLC: 070005.

Zghibi, A., Zouhri, L., Tarhouni, J., Kouzana, L., 2013. Groundwater mineralisation processes in Mediterranean semi-arid systems (Cap-Bon, North east of Tunisia): hydrogeological and geochemical approaches. Hydrological Processes, 27(22), 3227-3239.

Zhang, W., Chen, X., Tan, H., Zhang, Y., Cao, J., 2015. Geochemical and isotopic data for restricting seawater intrusion and groundwater circulation in a series of typical volcanic islands in the South China Sea. Marine pollution bulletin, 93(1-2), 153-162. 